\title{
The basic reproductive number and particle-to-plaque ratio: comparison of these two parameters of viral infectivity
}

\author{
Winston McCormick ${ }^{1}$ and Leonard A. Mermel $2,3^{*}$ (D)
}

\begin{abstract}
The COVID-19 pandemic has brought more widespread attention to the basic reproductive number $\left(R_{0}\right)$, an epidemiologic measurement. A lesser-known measure of virologic infectivity is the particle-to-plaque ratio (P:PFU). We suggest that comparison between the two parameters may assist in better understanding viral transmission dynamics.
\end{abstract}

Keywords: Basic reproductive number, Particle-to-plaque, Particle-to-pfu, COVID-19, Viral transmission

As the COVID-19 pandemic continues, attention has been brought to the epidemiologic measure known as the basic reproductive number $\left(\mathrm{R}_{\mathrm{o}}\right)$, the expected number of cases arising from an index case in a susceptible population [1-5]. The $R_{o}$ is differentiated from $R_{e}$ or $R_{t}$, the effective reproduction number, which accounts for public health measures such as vaccination, contact tracing, or social distancing $[2,5,6]$. The $R_{o}$ indicates the potential for viral transmission in a population. When $R_{o}>1$, the virus exhibits spread within a population, and when it is less than 1 , it does not have the potential to spread. The $R_{o}$ is determined from mathematical models and must be interpreted under the context that models are often imperfect. Indeed, to be a true reflection of the $R_{0}$, the model cannot involve any public health measures taken to delay viral transmission. A major limitation of $R_{o}$ is that it is difficult to compare $R_{o}$ values of two viruses if they are calculated using different models. Although there are many models to calculate $R_{o}$, SEIR compartmental method is among the simplest and widely used available methods [7]. The higher the $R_{0}$, the more public health measures must be expended to bring the $R_{e}<1$

\footnotetext{
*Correspondence: Imermel@lifespan.org

2 Department of Medicine, Warren Alpert Medical School of Brown University, 222 Richmond St, Providence, RI 02903, USA

Full list of author information is available at the end of the article
}

needed for an epidemic or pandemic to cease $[2,8]$. The $R_{o}$ can be manipulated to indicate parameters vital to control measures. For example, $R_{o}^{-1}$ is the endemic equilibrium proportion of the population that will remain susceptible, and $1-\frac{1}{R_{o}}$ alerts public health officials to the proportion of a population that must be immunized to acquire herd immunity [1]. Imprecision in determining $R_{o}$ can lead to public health measures that are either too relaxed or too strenuous, leading to spread that is not adequately controlled or burnout among the public in maintaining control measures. Nevertheless, $R_{o}$ can indicate vital information to assist in planning public health interventions.

A lesser known measure of infectivity is the particle to plaque-forming unit ratio (P:PFU; Table 1). The P:PFU measures the fraction of viral particles able to infect susceptible cells in tissue culture under idealized in vitro conditions [9-11]. When P:PFU approaches 1, as occurs with bacteriophages, each viral particle is able to complete an infectious cycle in a susceptible cell (i.e., highly infectious to the cells in tissue culture) [9, 10]. For many animal viruses, the ratio is on the order of $500-10,000$. There may be some uncertainty about this ratio since some viral particles used to infect cells in tissue culture may be nonviable $[9,11]$. A high P:PFU ratio is often attributed to viral particles with incomplete genomes, original author(s) and the source, provide a link to the Creative Commons licence, and indicate if changes were made. The images or other third party material in this article are included in the article's Creative Commons licence, unless indicated otherwise in a credit line to the material. If material is not included in the article's Creative Commons licence and your intended use is not permitted by statutory regulation or exceeds the permitted use, you will need to obtain permission directly from the copyright holder. To view a copy of this licence, visit http://creativecommons.org/licenses/by/4.0/. The Creative Commons Public Domain Dedication waiver (http://creativeco mmons.org/publicdomain/zero/1.0/) applies to the data made available in this article, unless otherwise stated in a credit line to the data. 
Table 1 Characteristics of viral transmission including the particle to plaque forming unit ratio assessed in cell culture and reproductive number assessed in epidemiologic studies

\begin{tabular}{|c|c|c|c|c|c|}
\hline Virus & Particle:PFU & $\mathbf{R}_{\mathrm{o}}$ & $\mathrm{R}_{\mathrm{o}} /$ Particle:PFU & Transmission & Notes \\
\hline $\begin{array}{l}\text { Ebola } \\
\text { (-ssRNA) }\end{array}$ & $511[12]$ & $1.5-1.9[21]$ & $2.9 \times 10^{-3}-3.7 \times 10^{-3}$ & Bodily Fluids & $\begin{array}{l}\text { Particle:PFU from strain at Walter } \\
\text { Reed Medical Center [1]; } R_{\circ} \\
\text { from } 2014 \text { epidemic [21] }\end{array}$ \\
\hline $\begin{array}{l}\text { Influenza } A^{*} \\
(-s s R N A)\end{array}$ & $20-509$ & $0.9-2.1[6]$ & $4.2 \times 10^{-2}-4.5 \times 10^{-2}$ & $\begin{array}{l}\text { Predominantly Respiratory } \\
\text { Droplet }\end{array}$ & Seasonal strains \\
\hline $\begin{array}{l}\text { Smallpox } \\
\text { (dsDNA) }\end{array}$ & $1-100[9,22]$ & $6.87[23]$ & $1.46 \times 10^{-1}-14.6$ & Small particle aerosol & Ro from 1967 outbreak smallpox \\
\hline $\begin{array}{l}\text { VZV } \\
(d s D N A)\end{array}$ & $40000[14]$ & $10-12[24]$ & $2.5 \times 10^{-4}-3 \times 10^{-4}$ & Small particle aerosol; Vertical & $\mathrm{R}_{\circ}$ pre-vaccine \\
\hline $\begin{array}{l}\text { Adenoviradae } \\
\text { (dsDNA) }\end{array}$ & $20-100[9]$ & $2.34[24]$ & $2.3 \times 10^{-2}-1.2 \times 10^{-1}$ & Fecal-oral; Respiratory & \\
\hline $\begin{array}{l}\text { Rotavirus } \\
\text { (dsRNA) }\end{array}$ & $10[9]$ & $78.8[26]$ & 7.88 & Fecal-oral; Droplet & $\mathrm{R}_{\mathrm{o}}$ pre-vaccine estimation \\
\hline $\begin{array}{l}\text { HSV-1* } \\
\text { (dsDNA) }\end{array}$ & $50-200[9]$ & $2-5[28]$ & $2 \times 10^{-2}-4 \times 10^{-2}$ & Bodily Fluids, Sexual, Vertical & $\begin{array}{l}\text { P:PFU antecedently recorded } \\
\text { as 10:1 }\end{array}$ \\
\hline $\begin{array}{l}\text { HSV-2 } \\
\text { (dsDNA) }\end{array}$ & $50-200[9]$ & $2.07[29]$ & $1 \times 10^{-2}-4 \times 10^{-2}$ & Sexual; Vertical & \\
\hline $\begin{array}{l}\text { Polio* } \\
\text { (+ ssRNA) }\end{array}$ & $36-1000[9,19]$ & $5-6[24]$ & $6 \times 10^{-3}-1.4 \times 10^{-1}$ & Fecal-oral & \\
\hline $\begin{array}{l}\text { HPV } \\
\text { (dsDNA) }\end{array}$ & $10000[9]$ & $0.52-1.2[30]$ & $5.2 \times 10^{-5}-1.2 \times 10^{-4}$ & Sexual & $\begin{array}{l}\text { STI strains; } R_{o} \text { assumes untreated } \\
\text { population; ignores autoin- } \\
\text { noculation }\end{array}$ \\
\hline $\begin{array}{l}\text { Coxsackie A } \\
(+s s R N A)\end{array}$ & $210[31]$ & $2.5[32]$ & $1.2 \times 10^{-3}$ & Fecal-oral & \\
\hline $\begin{array}{l}\text { Measles* } \\
\text { (-ssRNA) }\end{array}$ & $10-200[16,17]$ & $12-18[3]$ & $9 \times 10^{-2}-1.2$ & Small particle aerosol & $R_{o}$ pre-vaccine \\
\hline $\begin{array}{l}\text { RSV } \\
(-s S R N A)\end{array}$ & 3200 [33] & $1.2-3.0[25,34,35]$ & $3.8 \times 10^{-4}-9.4 \times 10^{-4}$ & Respiratory droplet; Fomite & \\
\hline $\begin{array}{l}\text { Mumps* } \\
(-s s R N A)\end{array}$ & $100-1000$ [13] & $10-12[24]$ & $1.2 \times 10^{-2}-1 \times 10^{-1}$ & Respiratory droplet & $R_{o}$ pre-vaccine \\
\hline $\begin{array}{l}\text { SARS-CoV } \\
\text { (+ SSRNA) }\end{array}$ & $360[36]$ & $2.2-3.6[4]$ & $6.1 \times 10^{-4}-1 \times 10^{-2}$ & Respiratory droplet & Particle:PFU from gRNA \\
\hline $\begin{array}{l}\text { Rhinovirus* } \\
\text { (+ ssRNA) }\end{array}$ & $30-1000[1,18]$ & $2-3[35]$ & $3 \times 10^{-3}-6.7 \times 10^{-2}$ & Respiratory droplet & $\begin{array}{l}\text { Inferred P:PFU; } R_{o} \text { seasonal } \\
\text { change }\end{array}$ \\
\hline $\begin{array}{l}\text { SARS-CoV-2 } \\
(+ \text { SSRNA) }\end{array}$ & $1000-1000000[20,37]$ & $2.6-5.7[27]$ & $5.7 \times 10^{-6}-2.6 \times 10^{-3}$ & $\begin{array}{l}\text { Respiratory droplet; possible } \\
\text { aerosol }\end{array}$ & $\begin{array}{l}\text { Early studies suggest } R_{0} \text { closer } \\
\text { to } 2.6\end{array}$ \\
\hline
\end{tabular}

VZV varicella zoster virus, HSV herpes simplex virus, HPV human papillomavirus. Only "true aerosol" diseases were classified as aerosol. [24] Minor routes of transmission (i.e., fomite, vertical, animal) were ignored for graphical analysis

structural capsid deficits, or lethal mutations [11]. The P:PFU ratio may add important insight into transmission dynamics of viral pathogens, especially when viral quantification is necessary $[9,12]$.

Multiple reference values for P:PFU ratios are from older literature that have not been revisited. Virologists often calculate P:PFU ratios for strains in their laboratories [13], but there are no standardized means of producing reference P:PFU ratios. Standardizing P:PFU ratio protocols and revisiting previously published data would be useful. For poliovirus, older sources document a P:PFU ratio ranging from 1000 to 30 and have not been revisited for since 1957 [9, 18, 19]. However, without a standardized means of collection, there is no way to assess which value is more accurate. Infective virions constituting $10 \%$ of a viral population vs. $0.5 \%$ of a population is a monumental difference which could have ramifications regarding transmission dynamics $[12,14,15]$. Furthermore, a lack of standardization may be associated with a wide range in P:PFU ratios for poliovirus, rhinovirus, and measles [9, 16-19]. In addition, P:PFU values must be interpreted with caution since viral passage in cell culture changes the P:PFU ratio as has been demonstrated for SARS-CoV-2 [20]. The inconsistency in cell line type (e.g., Vero 6 or HeLa cell lines) is another limitation due to lack of standardization [12]. Lastly, the P:PFU must be interpreted in context. A high P:PFU may represent defective 
interfering particles that have incomplete circular genomes and are unable to form plaques in culture but can still complete an infectious cycle in vivo by relying on complete helper genomes as reflected in one study in which high P:PFU strains of Ebola virus were still able to generate lethal infections [12].

We found inconsistencies among the dynamics of transmission for respiratory viruses. Influenza A virus has a lower P:PFU than respiratory syncytial virus (RSV), but RSV has a higher $R_{o}$. This may reflect less than idealized tissue culture conditions for RSV or much more efficient person-to-person RSV transmission. SARS-CoV and rhinovirus have higher P:PFU than Influenza A virus but also higher $R_{o}$. Perhaps this reflects the lack of ideal tissue culture conditions for SARS-Co-V and rhinovirus. With current limitations of P:PFU data, such discrepancies may be clarified when more tissue culture data are collected in a uniform manner.

Could an assessment of the $R_{\mathrm{o}} / \mathrm{P}$ :PFU ratio add to information garnered from either value alone as a virus such as SARS-CoV-2 evolves in its new human host? The new variants are evolving to more efficiently bind to ACE receptors on human cells [38] and this should lead to a lower P:PFU ratio, but it is unclear if or how this might affect person-to-person transmission of the virus, (i.e., affect the $R_{o}$ ). If the $R_{o} / P$ :PFU ratio rises more quickly than the $R_{o}$ alone, then it would suggest that improved receptor cell binding and/or cell entry did not translate into greater human-to-human transmission. Such comparisons may add insight as SARSCoV-2 and other viruses adapt to a new host.

\section{Conclusion}

As the COVID-19 pandemic continues the relationship between the P:PFU ratios and $R_{o}$ may add to our understanding of SARS-CoV-2 as variants evolve to adapt to the new human host.

\section{Abbreviations}

Ro: Basic reproductive number; P:PFU: Particle-to-plaque ratio; VZV: Varicella zoster virus; HSV: Herpes simplex virus; HPV: Human papillomavirus.

\section{Acknowledgements}

None.

\section{Authors' contributions}

LM had the idea for the project. WM wrote the first manuscript draft. LM made revisions to the draft. All authors read and approved the final manuscript.

\section{Funding}

This work was unfunded.

\section{Availability of data and materials} Not applicable.

\section{Declarations}

Ethics approval and consent to participate

Not applicable.

\section{Consent for publication}

The authors give consent for publication.

\section{Competing interests}

The authors declare that they have no competing interests.

\section{Author details}

${ }^{1}$ Warren Alpert Medical School of Brown University, 222 Richmond St, Providence, RI 02903, USA. ${ }^{2}$ Department of Medicine, Warren Alpert Medical School of Brown University, 222 Richmond St, Providence, RI 02903, USA. ${ }^{3}$ Department of Epidemiology \& Infection Control, and Division of Infectious Diseases, Rhode Island Hospital, 593 Eddy St, Providence, RI 02903, USA.

Received: 25 January 2021 Accepted: 23 April 2021

Published online: 30 April 2021

\section{References}

1. Brouwer AF, Meza R, Eisenberg MC. Transmission heterogeneity and autoinoculation in a multisite infection model of HPV. Math Biosci. 2015;270:115-25.

2. Delamater PL, Street EJ, Leslie TF, Yang YT, Jacobsen KH. Complexity of the basic reproduction number ( $\left.R_{0}\right)$. Emerg Infect Dis. 2019;2019(25):1-4.

3. Guerra FM, Bolotin S, Lim G, Heffernan J, Deeks SL, Li Y, et al. The basic reproduction number (R 0 ) of measles: a systematic review. Lancet Infect Dis. 2017;17:E420-8.

4. Lipsitch M, Cohen T, Cooper B, Robins JM, Ma S, James L, et al. Transmission dynamics and control of severe acute respiratory syndrome. Science. 2003;300:1966-70.

5. Viceconte G, Petrosillo N. COVID-19 R0: magic number or conundrum? Infect Dis Rep. 2020. https://doi.org/10.4081/idr.2020.8516.

6. Ferguson NM, Cummings DA, Fraser C, Cajka JC, Cooley PC, Burke DS. Strategies for mitigating an influenza pandemic. Nature. 2006;442:448-52.

7. Van den Driessche P. Reproduction numbers of infectious disease models. Infect Dis Model. 2017;2:288-303.

8. Chowell G, Hengartner N, Castillo-Chavez C, Fenimore P, Hyman J. The basic reproductive number of Ebola and the effects of public health measures: the cases of Congo and Uganda. J Theor Biol. 2004;229:119-26.

9. Racaniello V (2011) Are all virus particles infectious? Virology Blog. https:// www.virology.ws/2011/01/21/are-all-virus-particles-infectious/. Published January 21, 2011. Accessed 02 Aug 2020

10. Brooke CB. Biological activities of "noninfectious" influenza A virus particles. Future Virol. 2014;2014(9):41-51.

11. Sanjuán R. Collective properties of viral infectivity. Curr Opin Virol. 2018;33:1-6.

12. Alfson KJ, Avena LE, Beadles MW, Staples H, Nunneley JW, Ticer A, et al. Particle-to-PFU ratio of Ebola virus influences disease course and survival in cynomolgus macaques. J Virol. 2015;89:6773-81.

13. Chen H, Ngo L, Petrovskaya S, Gao Y, Laassri M, Rubin S. Purification of mumps virus particles of high viability. J Virol Methods. 2016;233:6-9.

14. Carpenter JE, Henderson EP, Grose C. Enumeration of an extremely high particle-to-PFU ratio for varicella-zoster virus. J Virol. 2009;83:6917-21.

15. Klasse PJ. Molecular determinants of the ratio of inert to infectious virus particles. Prog Mol Biol Transl Sci. 2015;2015:285-326.

16. Arita M, Matumoto M. Plaque formation and initial virus-cell interaction of measles virus. Jpn J Microbiol. 1968;12:51-61.

17. Matumoto M. Multiplication of measles virus in cell cultures. Bacteriol Rev. 1966;30:152-76.

18. Racaniello VP (2020) The Viruses and their replication. Basic Medical Key. https://basicmedicalkey.com/picornaviridae-the-viruses-and-their-repli cation/. Published August 11, 2016. Accessed 02 Aug 2020

19. Schwerdt CE, Fogh J. The ratio of physical particles per infectious unit observed for poliomyelitis viruses. Virology. 1957:4:41-52. 
20. Klimstra WB, Tilston-Lunel NL, Nambulli S, et al. SARS-CoV-2 growth, furincleavage-site adaptation and neutralization using serum from acutely infected hospitalized COVID-19 patients. J Gen Virol. 2020;101:1156-69.

21. Naveed M, Khan A, Dur-E-Ahmad M, Imran M. Estimating the basic reproductive ratio for the Ebola outbreak in Liberia and Sierra Leone. Infect Dis Poverty. 2015;4:13. https://doi.org/10.1186/s40249-015-0043-3.

22. Baker $\mathrm{J}$, Ward BM. Development and comparison of a quantitative TaqMan-MGB real-time PCR assay to three other methods of quantifying vaccinia virions. J Virol Methods. 2014;196:126-32.

23. Eichner M, Dietz K. Transmission potential of smallpox: estimates based on detailed data from an outbreak. Am J Epidemiol. 2003;158:110-7.

24. Tang J, Li Y, Eames I, Chan P, Ridgway G. Factors involved in the aerosol transmission of infection and control of ventilation in healthcare premises. J Hosp Infect. 2006;64:100-14.

25. Spencer J, Shutt DP, Moser SK, Clegg H, Wearing HJ, Mukundan H, et al. Epidemiological parameter review and comparative dynamics of influenza, respiratory syncytial virus, rhinovirus, human coronavirus, and adenovirus. medRxiv. 2020; https://doi.org/10.1101/2020.02.04.20020404.

26. Pitzer VE, Bennett A, Bar-Zeev N, Jere KC, Lopman BA, Lewnard JA, et al. Evaluating strategies to improve rotavirus vaccine impact during the second year of life in Malawi. Sci Transl Med. 2019. https://doi.org/10. 1126/scitranslmed.aav6419.

27. Sanche S, Lin YT, Xu C, Romero-Severson E, Hengartner N, Ke R. High contagiousness and rapid spread of severe acute respiratory syndrome coronavirus 2. Emerg Infect Dis. 2020;26:1470-7.

28. Lipsitch M, Bacon TH, Leary JJ, Antia R, Levin BR. Effects of antiviral usage on transmission dynamics of herpes simplex virus type 1 and on antiviral resistance: predictions of mathematical models. Antimicrob Agents Chemother. 2000;44:2824-35.

29. Wang J, Yu X, Tessmer HL, Kuniya T, Omori R. Modelling infectious diseases with relapse: a case study of HSV-2. Theor Biol Med Model. 2017. https://doi.org/10.1186/s12976-017-0059-4.
30. Lee SL, Tameru AM. A mathematical model of human papillomavirus (HPV) in the United States and its impact on cervical cancer. J Cancer. 2012;3:262-8

31. Belsham GJ, Bostock CJ. Studies on the Infectivity of foot-and-mouth disease virus RNA using microinjection. J Gen Virol. 1988;1988(69):265-74.

32. Ma E, Fung C, Yip SH, Wong C, Chuang SK, Tsang T. Estimation of the basic reproduction number of enterovirus 71 and coxsackievirus A16 in hand, foot, and mouth disease outbreaks. Pediatr Infect Dis J. 2011;30:675-9.

33. Szakács Z, Mészáros T, Jonge MI, Gyurcsányi RE. Selective counting and sizing of single virus particles using fluorescent aptamer-based nanoparticle tracking analysis. Nanoscale. 2018;10:13942-8.

34. Barr R, Green CA, Sande CJ, Drysdale SB. Respiratory syncytial virus: diagnosis, prevention and management. Ther Adv Infect Dis. 2019. https://doi. org/10.1177/2049936119865798.

35. Reis J, Shaman J. Simulation of four respiratory viruses and inference of epidemiological parameters. Infect Dis Model. 2018;3:23-34.

36. Vicenzi E, Canducci F, Pinna D, et al. Coronaviridae and SARS-associated Coronavirus Strain HSR1. Emerg Infect Dis. 2004;10:413-8.

37. Ghezzi S, Pagani I, Poli G, Perboni S, Vicenzi E. Rapid Inactivation of Severe Acute Respiratory Syndrome Coronavirus 2 (SARS-CoV-2) by Tungsten Trioxide-Based (WO3) Photocatalysis. bioRxchive. August 2020. https://doi. org/10.1101/2020.08.01.232199.

38. Ozono S, Zhang Y, Ode H, et al. SARS-CoV-2 D614G spike mutation increases entry efficiency with enhanced ACE2-binding affinity. Nat Commun. 2021. https://doi.org/10.1038/s41467-021-21118-2.

\section{Publisher's Note}

Springer Nature remains neutral with regard to jurisdictional claims in published maps and institutional affiliations.
Ready to submit your research? Choose BMC and benefit from:

- fast, convenient online submission

- thorough peer review by experienced researchers in your field

- rapid publication on acceptance

- support for research data, including large and complex data types

- gold Open Access which fosters wider collaboration and increased citations

- maximum visibility for your research: over $100 \mathrm{M}$ website views per year

At BMC, research is always in progress.

Learn more biomedcentral.com/submissions 